\title{
New Trends in Higher Education and Challenges and Emerging Opportunities in Business Education
}

\author{
Nadeem Bhatti ${ }^{1}$, Anwar Ali Shah G. Syed ${ }^{2}$, Ghulam Murtaza Maitlo ${ }^{3}$ \& Faiz. M. Shaikh ${ }^{4}$ \\ ${ }^{1}$ North American College, Toronto, Canada \\ 2 Pro-Vice Chancellor University of Sindh-Dadu Campus, Sindh, Pakistan \\ ${ }^{3}$ Deptt: of Commerce SALU-Khairpur Mirs, Sindh, Pakistan \\ ${ }^{4}$ SZABAC, Dokri, Larkana, Sindh, Pakistan \\ Correspondence: Faiz. M. Shaikh, Assistant Professor, SZABAC, Dokri, Larkana, Sindh, Pakistan. E-mail: \\ faizanmy2000@hotmail.com
}

$\begin{array}{lc}\text { Received: October 11, } 2011 & \text { Accepted: February 2, 2012 Published: June 1, } 2012 \\ \text { doi:10.5539/ass.v8n7p86 } & \text { URL: http://dx.doi.org/10.5539/ass.v8n7p86 }\end{array}$

\begin{abstract}
This research investigates the new trends in Higher education and challenging and emerging opportunities in Business education. A complementary survey was conducted from 50 organizations in Sindh province by using simple random technique, and 200 sample size were selected from student data set. The results showed that higher education trends are dramatically changed in few decades. It was revealed that Business education is the first priority of the $90 \%$ of the students in Pakistan. It was further revealed that business education also emerging with new disciplines according to the market demand i.e. Knowledge management, MIS and Stress management these are the key areas where students and organizations are interested. There are numerous job opportunities in the business related degrees. It was further revealed that new trends in business education open the window of multinational organizations for creating job opportunities for the graduates of business.
\end{abstract}

Keywords: trends, emerging, business education

\section{Introduction}

The purpose of this research I to investigates the modern tools which are used in the business field and its impact on emerging opportunities in Business Education. From last decade business education getting importance because of the job markets and emerging opportunities in Pakistan.

The purpose of this research that how business education play a key role in the job performance of the graduates of business, when they are working in different fields and how help their in job satisfaction. After graduation how internship helps them in getting job and builds their leadership qualities when they are working in the external environmental. We have conducted interviews from fifty firms and organizations regarding the impact of case study teaching method on performance of graduates of business from IBA-University of Sindh-Jamshoro. In the process of answering this overall question, we also concerning student's priorities in time allocation versus how firms feel students should allocate their time. We also consider how these allocation decisions differ by certain student's characteristics such as gender and GPA, and by certain firm characteristics, such as type of firm (e.g. food manufacturer) and sales. In the following section we review the literature. Knowledge gaps exists not so much regarding what should be done (what is good)as they do regarding how intensively a student should engage in an activity. The literature examining University education in relation to case study approach and how its impact on the job performance. With the exception of some recent important work by Barkley and Barkley, stock and Sylvie's, and F.M.Shaikh little is known about the relationship between the case studies method impact starting salary and skill sets or indicators. Given that many students are getting high paying jobs, it is important that professors be able to provide the most accurate information available regarding the value of alternative career preparation steps. (et al Barkley).

\subsection{Current Salary Models}

The analyzing record of 100 graduates of business and are working in the technical, non-technical, government as well private organization. Examine their potential in job market and case approach help them regarding their personal as well as their impact on the job performance. We have randomly selected 200 graduates from Department of Business Administration IBA-University of Sindh-Jamshoro from graduate batches of, 1997 to, 2010. However, job search through personal relationship was found to be positive associated with starting salaries, where as job search through one's work experience was positively associated with starting salary. 


\section{Survey Design and Data}

The student must know the benefits from each activity to allocate time optimally across activities. This type of information potentially cab be obtained in one or two ways: (1) use observational data on salaries and activities to estimate the benefits associated with each activity; (11) survey employers and ask how they would rank alternative activities in terms of importance. Not surprisingly, each approach has its advantages and disadvantages. The literature to date has focused on the first approach of using observational data to estimate the benefits from each activity. Starting salary is regressed on several determinants such as GPA percentage, and case analysis ability then inferences are drawn regarding the marginal impact of the variable on the starting salary. The advantage of this approach is that the data reflects actual market conditions and salary offers. The alternative way of ascertaining how employers value different characteristic of the students is to conduct a survey and ask them directly. The main disadvantage of this approach is that answers to surveys may not be the same as actual employer behavior. However, the advantage is that the employer and student's valuations are not confounded in the measurement. The survey approach should therefore not to be considered a substitute for observational data based studies, but rather should be considered complementary approach that may shed a different light on the same issue.

\subsection{Employer Dataset}

Survey dataset were collected via two separate sampling efforts, one pertaining to employers and the other pertaining to business graduates-students of IBA-University of Sindh-Jamshoro. The employer data were collected from Organizations, firms, food market, marketing, banks, multinationals, food chains and was intended to correspond to the job market served by Gradates of business administration department IBA-University of Sindh-Jamshoro. Employers selected to participate in the study were those with a national reputation in their industry segment. Once cooperating individual was identified, a one-page questionnaire was fixed to that individual. Occasionally, firms returned a completed survey on the same day. Those firms not responding were called again or sent additional faxes. The producer was to continue contacting each employer until receiving either a completed questionnaire or a refusal. In all cases, those responding had an intimate knowledge of their firms hiring practices. In smaller firms the questionnaire was usually completed by one of the company owners. In large firms the questionnaire was often completed by some one in personnel department who specialized in hiring decisions. In all cases, an effort was made to find a person with appropriate authority with in each firm. The firm's survey was administered during a period extending from the fall 2005 to spring 2009-10. In total 50 different firms were contacted of which 29 firms participated for a response rate of over $98 \%$. As in all survey work, non-response bias warrants cautious inference.

Table 1. Description of surveyed firms

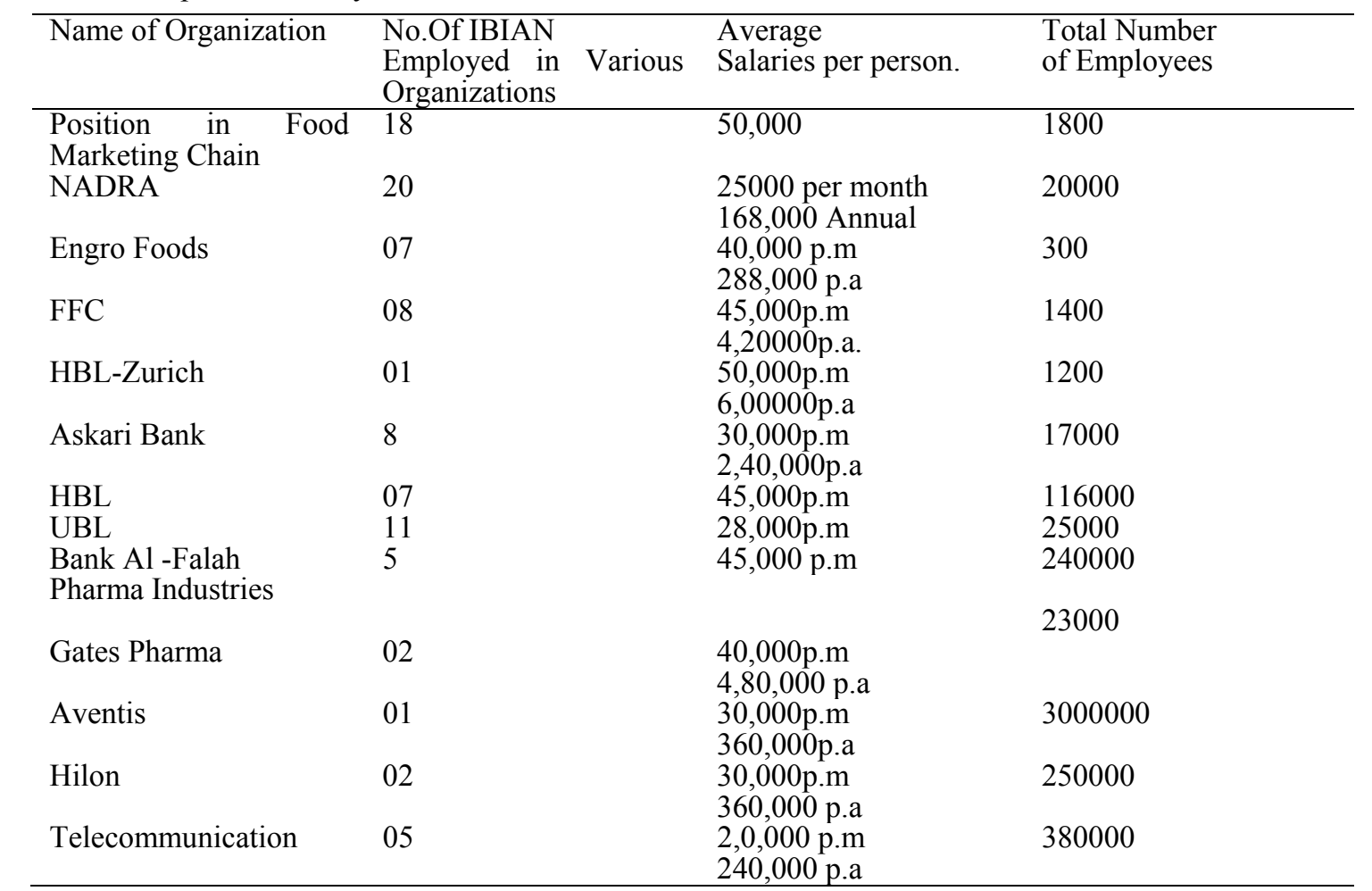

Source-Survey-2010-11 
Table 2. Description of surveyed students

\begin{tabular}{|c|c|}
\hline Students Characteristics & Mean Standard Deviation \\
\hline \multirow[t]{2}{*}{ Class 1997 Batch } & 0.03 \\
\hline & $(0.04)$ \\
\hline \multirow[t]{2}{*}{ Class. 98} & 0.05 \\
\hline & $(0.21)$ \\
\hline \multirow[t]{2}{*}{ Class.99 } & 0.22 \\
\hline & $(0.41)$ \\
\hline \multirow[t]{2}{*}{ Class.2000 } & 0.40 \\
\hline & $(0.49)$ \\
\hline \multirow[t]{2}{*}{ Class.2001 } & 0.24 \\
\hline & $(0.43)$ \\
\hline \multirow[t]{2}{*}{ Class.2002 } & 0.06 \\
\hline & $(0.23)$ \\
\hline \multirow[t]{2}{*}{ Class-2003 } & 0.07 \\
\hline & $(0.34)$ \\
\hline \multirow[t]{2}{*}{ Class-2004 } & 0.072 \\
\hline & $(0.28)$ \\
\hline \multirow[t]{2}{*}{ Class-2005 } & 0.076 \\
\hline & $(0.30)$ \\
\hline \multirow[t]{2}{*}{ Class-2006 } & 0.081 \\
\hline & $(0.32)$ \\
\hline \multirow[t]{2}{*}{ Class-2007 } & 0.080 \\
\hline & $(0.031)$ \\
\hline \multirow[t]{2}{*}{ Class-2008 } & 0.070 \\
\hline & $(0.279)$ \\
\hline \multirow[t]{2}{*}{ Class.2009 } & $0.091)$ \\
\hline & $(0.55)$ \\
\hline \multirow[t]{2}{*}{ Class.2010 } & $(0.69)$ \\
\hline & $(0.51)$ \\
\hline \multicolumn{2}{|l|}{ Class-2008 } \\
\hline & $(0.49)$ \\
\hline \multirow[t]{2}{*}{ Class-2009 } & $(0.03)$ \\
\hline & $0.091)$ \\
\hline \multirow[t]{2}{*}{ Class-2010 } & $(0.55)$ \\
\hline & $(0.69)$ \\
\hline
\end{tabular}


Table 3. General linear model time allocation selected by Students to receive a maximum starting salary

\begin{tabular}{|c|c|c|c|c|c|c|}
\hline & $\begin{array}{l}\text { Technical Course } \\
\text { Work(TCW) }\end{array}$ & $\begin{array}{l}\text { Raising } \\
\text { GPA } \\
\text { (RGPA) }\end{array}$ & $\begin{array}{l}\text { Work or } \\
\text { Internship } \\
\text { Experience } \\
\text { (WIE) } \\
\end{array}$ & $\begin{array}{l}\text { Leadership } \\
\text { Experience } \\
\text { Campus(LEC) }\end{array}$ & $\begin{array}{l}\text { Interview } \\
\text { Preparation) }\end{array}$ & F-test \\
\hline Mean \% & $0.2711^{*}$ & $0.2397 *$ & $0.2222^{*}$ & $0.2212^{*}$ & $0.1455^{*}$ & 13.75 \\
\hline Time & $(0.0001$ & 0.0002 & 0.0001 & 0.0001 & 0.0001 & 0.0001 \\
\hline Deviation & $\begin{array}{l}\text { From Mean } \% \\
\text { Time }\end{array}$ & & & & & \\
\hline $\begin{array}{l}\text { Class of } \\
95\end{array}$ & $\begin{array}{l}-0.03369 \\
(0.3307)\end{array}$ & $\begin{array}{l}0.0208 \\
(0.5485)\end{array}$ & $\begin{array}{l}0.0243 \\
(0.4826)\end{array}$ & $\begin{array}{l}-0.0033 \\
(0.9233)\end{array}$ & $\begin{array}{l}-0.0059 \\
(0.8655)\end{array}$ & $\begin{array}{l}0.47 \\
(0.87)\end{array}$ \\
\hline 96 & $\begin{array}{l}-0.03470 \\
(0.2539)\end{array}$ & $\begin{array}{l}0.0410 \\
(0.1787)\end{array}$ & $\begin{array}{l}0.00270 \\
(0.9297)\end{array}$ & $\begin{array}{l}0.0082 \\
(0.7885)\end{array}$ & $\begin{array}{l}0.0009 \\
(0.9770)\end{array}$ & $\begin{array}{l}0.64 \\
(0.67)\end{array}$ \\
\hline 97 & $\begin{array}{l}-0.0473 \\
(0.1132)\end{array}$ & $\begin{array}{l}0.0562 \\
(0.0602)\end{array}$ & $\begin{array}{l}-0.0097 \\
(0.7451)\end{array}$ & $\begin{array}{l}0.0035 \\
(0.9057)\end{array}$ & $\begin{array}{l}0.0027 \\
(0.9287)\end{array}$ & $\begin{array}{l}1.23 \\
(0.29)\end{array}$ \\
\hline 98 & $\begin{array}{l}-0.022 \\
(0.2333)\end{array}$ & $\begin{array}{l}0.0552 \\
(0.12343)\end{array}$ & $\begin{array}{l}0.00453 \\
(0.000543)\end{array}$ & $\begin{array}{l}(0.06675) \\
-00.6756\end{array}$ & $\begin{array}{l}(0.08978) \\
0.06553\end{array}$ & $\begin{array}{l}0.66 \\
(0.65)\end{array}$ \\
\hline 99 & $\begin{array}{l}-0.34555 \\
(0.4543)\end{array}$ & $\begin{array}{l}0.223132 \\
(0.29799)\end{array}$ & $\begin{array}{l}-0.56565 \\
(0.68757)\end{array}$ & $\begin{array}{l}-0.65345 \\
(0.25634)\end{array}$ & $\begin{array}{l}-0.5645 \\
(0.22333)\end{array}$ & $\begin{array}{l}0.70 \\
(0.68)\end{array}$ \\
\hline 2000 & $\begin{array}{l}-0.22345 \\
(0.2334)\end{array}$ & $\begin{array}{l}-0.5757 \\
(0.4363)\end{array}$ & $\begin{array}{l}-0.06675 \\
(0.2345)\end{array}$ & $\begin{array}{l}-0.45452 \\
(0.45434)\end{array}$ & $\begin{array}{l}-0.0655 \\
(0.45643)\end{array}$ & $\begin{array}{l}0.75 \\
(0.72)\end{array}$ \\
\hline 2001 & $\begin{array}{l}-0.300 \\
(0.3794)\end{array}$ & $\begin{array}{l}-0.0543 \\
(0.1269)\end{array}$ & $\begin{array}{l}-0.67867 \\
(0.9315)\end{array}$ & $\begin{array}{l}-0.05645 \\
(0.7055)\end{array}$ & $\begin{array}{l}-0.334 \\
(0.08158)\end{array}$ & $\begin{array}{l}0.80 \\
(0.76)\end{array}$ \\
\hline 2002 & $\begin{array}{l}-0.088 \\
(0.8413)\end{array}$ & $\begin{array}{l}-0.0360 \\
(0.56465)\end{array}$ & $\begin{array}{l}-0.0007 \\
(0.78676)\end{array}$ & $\begin{array}{l}-0.00087 \\
(0.78786)\end{array}$ & $\begin{array}{l}-0.0898 \\
(0.564654)\end{array}$ & $\begin{array}{l}0.85 \\
(0.81)\end{array}$ \\
\hline 2003 & $\begin{array}{l}-0.0678 \\
(0.7857)\end{array}$ & $\begin{array}{l}-0.06876 \\
(0.57657)\end{array}$ & $\begin{array}{l}-0.02786 \\
(0.6868)\end{array}$ & $\begin{array}{l}-0.678687 \\
(0.65589)\end{array}$ & $\begin{array}{l}-0.07979 \\
(0.7896)\end{array}$ & $\begin{array}{l}0.90 \\
(0.85)\end{array}$ \\
\hline 2004 & $\begin{array}{l}-0.0088 \\
(0.8414)\end{array}$ & $\begin{array}{l}-0.0360 \\
(0.4115)\end{array}$ & $\begin{array}{l}-0.0085 \\
(0.56545)\end{array}$ & $\begin{array}{l}-0.07876 \\
(0.267856)\end{array}$ & $\begin{array}{l}-0.022 \\
(0.2333)\end{array}$ & $\begin{array}{l}0.93 \\
(0.89)\end{array}$ \\
\hline 2005 & $\begin{array}{l}-0.03241 \\
(0.41234\end{array}$ & $\begin{array}{l}-0.008165 \\
(0.5764)\end{array}$ & $\begin{array}{l}-0.65765 \\
(0.267856)\end{array}$ & $\begin{array}{l}-0.023 \\
(0.32132)\end{array}$ & $\begin{array}{l}0.01237 \\
(0.78676\end{array}$ & $\begin{array}{l}0.75 \\
(0.81)\end{array}$ \\
\hline 2006 & $\begin{array}{l}-0.02141 \\
(0.32234\end{array}$ & $\begin{array}{l}-0.00724 \\
(0.5689)\end{array}$ & $\begin{array}{l}-0.63564 \\
(0.2878)\end{array}$ & $\begin{array}{l}-0.62436 \\
(0.3246)\end{array}$ & $\begin{array}{l}0.0067 \\
(0.78676\end{array}$ & $\begin{array}{l}0.5 \\
(0.81)\end{array}$ \\
\hline 2007 & $\begin{array}{l}-0.22345 \\
(0.2334) \\
\end{array}$ & $\begin{array}{l}-0.5757 \\
(0.4363) \\
\end{array}$ & $\begin{array}{l}-0.06675 \\
(0.2345) \\
\end{array}$ & $\begin{array}{l}-0.45452 \\
(0.45434) \\
\end{array}$ & $\begin{array}{l}-0.0655 \\
(0.45643)\end{array}$ & $\begin{array}{l}0.75 \\
(0.72) \\
\end{array}$ \\
\hline 2008 & $\begin{array}{l}-0.300 \\
(0.3794)\end{array}$ & $\begin{array}{l}-0.0543 \\
(0.1269)\end{array}$ & $\begin{array}{l}-0.67867 \\
(0.9315)\end{array}$ & $\begin{array}{l}-0.05645 \\
(0.7055)\end{array}$ & $\begin{array}{l}-0.334 \\
(0.08158)\end{array}$ & $\begin{array}{l}0.80 \\
(0.76)\end{array}$ \\
\hline $2009-10$ & $\begin{array}{l}-0.088 \\
(0.8413) \\
\end{array}$ & $\begin{array}{l}-0.0360 \\
(0.56465)\end{array}$ & $\begin{array}{l}-0.0007 \\
(0.78676)\end{array}$ & $\begin{array}{l}-0.00087 \\
(0.78786) \\
\end{array}$ & $\begin{array}{l}-0.0898 \\
(0.564654)\end{array}$ & $\begin{array}{l}0.85 \\
(0.81)\end{array}$ \\
\hline
\end{tabular}

Survey-2010-11

\section{Students Dataset}

How closely do these firm's hiring practices compare to students perceptions Seeking answer to this question, during the fall of 2000-07-08 a student survey was conducted in the classes taught by the management sciences department, IBA-University of Sindh-Jamshoro. As with the firms, students were asked the same question regarding the case analysis and various applications of case studies. Most of the multinational companies like Shell, Admore, Caltex, and OMV all they are hiring those business graduates who have strong knowledge about the case study analysis. Students were also asked to supply background information regarding their graduation class year, current GPA and their graduate school plans. Both the mean and standard deviations are presented for each student characteristics. Forty percent of the students were in the class of 1996. An additional $30 \%$ were in class 2000 and $33 \%$ were in class of 2007-08. Eighty percent of the students surveyed were male. The average GPA was 2.70 on a 4.0 scale. 


\section{Students Model and Results}

The statistical model for the student data takes the same general form as the firm model, but the interaction design matrix is defined differently. The student model is of the same form.

$$
Y=\mu+X_{1} \beta_{1}+X_{2}\left(X_{1}\right) \beta_{2}+\varepsilon
$$

Where now $\mathbf{Y}$ is the $\boldsymbol{m n} \boldsymbol{x} \mathbf{1}$ vector of allocation time stated by students $\boldsymbol{\mu}$ is the overall allocation time mean for students, $\mathbf{X} \mathbf{1}$ is a $\boldsymbol{m n} \boldsymbol{n}$ vector of main or treatment effects (i.e the five time allocation categories ) $\mathrm{X}_{2} \mathrm{X}_{1}$ is a $\boldsymbol{m n}$ $\boldsymbol{x} \boldsymbol{m} \boldsymbol{k}$ matrix of interaction of cross effect between the student characteristics (i.e. classes of 1995-2005 batches) male GPA planning graduates of business of IBA-University of Sindh-Jamshoro and the treatment effect $\boldsymbol{\beta}_{1}$ and $\boldsymbol{\beta}_{2}$ are conformable parameter vectors, and $\boldsymbol{\varepsilon}$ is disturbance term. The index $m$ denotes the number of categories, which again is five and the index $n$ now denotes the number of students, which is 100 .

\subsection{Results}

Comparison to the results of table.2.for firms with those in Table.3 for students indicates certain differences between the firms and students responses. To statically test these differences, a general linear model can once again be implemented by redefining the matrix. The model is again of the form

$$
Y=\mu+X 1 \beta 1+X 2(X 1) \beta 2+\epsilon
$$

Where $\mathrm{Y}=\mathrm{mn} \chi 1$ vector of allocation time mean for student and firms, $\mathrm{X} 1$, is $\mathrm{mn} \chi \mathrm{m}$ vector of amin or treatment. Again $\beta 1, \beta 2$ are parameters vectors $\in$ is the disturbance term, $m=$ number of categories.

\section{Conclusion}

The focus of this study to investigates the business education and emerging opportunities for the graduates of IBA-University of Sindh and modern tools and methods is only way to get practical exposure of the business graduates, it help students when they are working in different jobs, in domestic as well as multinational companies. Job market performance of graduate's business IBA-University of Sindh-Jamshoro of is positive associated and their furnished product build better image in Sukkur and their vicinity. The graduates of Business administration of IBA-University of Sindh-Jamshoro there are enjoying the high salaries and they are working in multinational s as well as domestic base companies in Pakistan specially Sukkur and their vicinity, salaries believe in merit, quality and Excellence. The graduate of Business compare to other business schools in interior Sindh has a good brand image. Which they are producing according to the demand of the market in Pakistan as well overseas. Case study method is only way to enhance the knowledge of business graduate and positively associated with the job market performance.

\section{References}

Barkley, A.P, W.A.Stock, \& C.K. (1999, November). Sylvie's Business Graduate Earnings. Am. J. O. A. Economics, 81, 785-800.

Deaton, A., \& J. Mueller. (1980). Economics and Consumer behavior. Cambridge University press.

Economic Survey of Pakistan 2004-05. Ministry of finance, Government of Pakistan.

Jaforullah, M. (1993). Asymmetric supply response: evidence from Bangladesh. Journal of Agricultural Economics, 44, 490-495. http://dx.doi.org/10.1111/j.1477-9552.1993.tb00290.x

Lim, S.L. (1999). The supply response of primary producers' Penerbit University Malaysia.

Maitha, J.K. (1970). Productivity response to price, A case study of Kenyan coffee. East African Economic Review, 2, 31-37.

Ogbu, O. M., \& Gwetibou, M. (1990). Agricultural supply response in sub-Saharan a critical review of the literature. Afr. Dev. Rev., 2, 83-99. http://dx.doi.org/10.1111/j.1467-8268.1990.tb00025.x

Rao J. M. (1989). Agricultural supply response: a survey. Agric. Eco., 3, 1-22. http://dx.doi.org/10.1016/0169-5150(89)90036-4

S. M. Nasir. Economics of Pakistan ( $5^{\text {th }}$ ed.). Salma publishers, Lahore.

Shaikh Mubarak Ali. Economy of Pakistan Rehber publishers, Urdu Bazaar Karachi.

Sherma, K. L. (1992). Aggregate farm supply response in Kenya. East American Economic Review. 